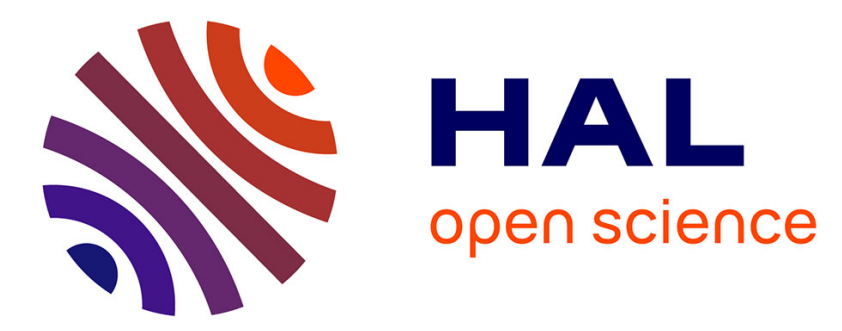

\title{
Osseous technology as a reflection of chronological, economic and sociological aspects of Palaeolithic hunter-gatherers: Examples from key Aurignacian and Gravettian sites in South-West Europe
}

Nejma Goutas, José-Miguel Tejero

\section{To cite this version:}

Nejma Goutas, José-Miguel Tejero. Osseous technology as a reflection of chronological, economic and sociological aspects of Palaeolithic hunter-gatherers: Examples from key Aurignacian and Gravettian sites in South-West Europe. Quaternary International, 2016, 403, pp.79-89. 10.1016/j.quaint.2015.11.143 . hal-01961331

\section{HAL Id: hal-01961331 \\ https://hal.science/hal-01961331}

Submitted on 19 Dec 2018

HAL is a multi-disciplinary open access archive for the deposit and dissemination of scientific research documents, whether they are published or not. The documents may come from teaching and research institutions in France or abroad, or from public or private research centers.
L'archive ouverte pluridisciplinaire HAL, est destinée au dépôt et à la diffusion de documents scientifiques de niveau recherche, publiés ou non, émanant des établissements d'enseignement et de recherche français ou étrangers, des laboratoires publics ou privés. 


\title{
Osseous technology as a reflection of chronological, economic and sociological aspects of Palaeolithic hunter-gatherers: Examples from key Aurignacian and Gravettian sites in South-West Europe
}

\author{
Nejma Goutas ${ }^{a,}{ }^{*}, 1$, José-Miguel Tejero ${ }^{\text {a, b, } 1}$ \\ ${ }^{a}$ CNRS, ArScan, UMR-7041, Ethnologie préhistorique, MAE - Maison René Ginouvès - Archéologie \& Ethnologie, 21, allée de l'Université, F-92023 Nanterre \\ Cedex, France \\ b SERP (Seminari d'Estudis i Recerques Prehistoriques), Barcelona University, Spain
}

\section{A R T I C L E I N F O}

\section{Article history:}

Available online 12 February 2016

\section{Keywords:}

Technology

Osseous industry

Aurignacian

Gravettian

France

Spain

\begin{abstract}
A B S T R A C T
Typological studies applied on the osseous industry developed slowly in France following the pioneering work of H. Camps-Fabrer and the technological renewal that F. Billamboz and D. Stordeur brought to this field in the 1970-1980s. This field has been thriving since the 2000s. Technology represents part of a systemic approach where each component of a technical system is analysed as to its purpose, its structure and its connection to other components of the socio-economic system. Nevertheless, technology is not an end in itself. Any technological observation must be considered in its sociological and palaeohistorical context in order to understand, not only the activities that took place during the occupation of a site, but more broadly to translate these data into "a realistic story of human behaviours". That is why reducing osseous technology to analysis of technical stigmata alone oversimplifies the potentials of this approach. We will illustrate this topic using Aurignacian and Gravettian examples from a few key French and Spanish sites. By showing technical and conceptual differences in the manufacturing of osseous projectile points (e.g. split-based points) in assemblages usually considered homogeneous, we can infer the existence of different techno-typological traditions and discuss if they are - or not - representative of different cultural traditions. Various technical details such as splitting base preparation by scraping, are significant indicators allowing discussion of whether there was diffusion of ideas and/or human groups from one side of the Pyrenees to the other at the beginning of the Upper Palaeolithic.
\end{abstract}

(c) 2016 Elsevier Ltd and INQUA. All rights reserved.

\section{Introduction}

How can technology help us to overcome the lack of new osseous industry data from archaeological sources? And how can technology of bone assemblages allow us to look at technical choice as a reflection of cultural boundaries? These are the questions we want address in this paper from two different but complementary technological angles.

First, we will see how technology allows us to re-evaluate the representativeness of osseous assemblages from old excavations: highlighting stratigraphic, taphonomic and technological inconsistencies (Goutas, 2004; Pétillon, 2006; Lacarrière et al., 2011; Tejero, 2013). Secondly, we will show how the technology

\footnotetext{
* Corresponding author.

E-mail address: nejma.goutas@mae.u-paris10.fr (N. Goutas).

1 GDRI Prehistos Members.
}

of production of worked osseous material can and should be a "privileged partner" of lithic technology and other kinds of material culture data for the chrono-cultural and regional seriation of Palaeolithic groups (Averbouh, 2000; Goutas, 2013a, 2013b; Tejero, 2014; Pétillon et al., 2015; Tejero and Grimaldi, 2015). We will use two examples to illustrate our point of view. The first example will focus on the traditions of shaping of Aurignacian split-based points (synchronic and regional approaches). The second example will be a diachronic approach dealing with the tradition of antler debitage by comparing the different ways employed during Aurignacian and Gravettian to remove particular kinds of blanks: the rods. These rods were mainly (Gravettian) and sometimes exclusively (Aurignacian) involved in the manufacturing of hunting weapons.

Discussing the technological approach and its methodological, palethnological (sensu Leroi-Gourhan) and paleohistorical (sensu Valentin, 2006) implications requires first revisiting a number of concepts and definitions that are closely linked with it, starting 
with typology. Similarly, we cannot consider technology as a way to identify cultural traditions without discussing knowledge and know-how (sensu Pelegrin, 1991). As pointed out by Choyke (2009: 21 ) "individual and collective memory expressed by and through the traditional material culture surrounding and exploited by people is one way both individuals and social groups maintain social cohesion".

The identification of techno-economic traditions (in terms of acquisition, processing and use) implemented in the work of hard animal materials in a given territory and time, is thus one of the objectives and objectified means to report on the existence, the variability, the evolution, the maintenance or the disappearance of cultural identities. In this sense, these technical traditions represent a way to highlight real social interactions between different human groups.

The acquisition of a technique (in the anthropological and archaeological understanding) or a language, necessarily implies a social setting, because it is always "socially learned" and "socially transmitted" and not the result of "an inspired creation that came from the nothingness" (Haudricourt, 1965: 36). "In technology, as elsewhere, there is no creation ex nihilo, a sudden jump. Every invention, every innovation is only the combination of pre-existing elements borrowed from the surrounding environment, from already known techniques" [authors' translation] (Haudricourt, 1965: 33). This is what F. Sigaut illustrates through the "myth of Robinson Crusoe, the shipwrecked man, able to rebuild his society on his own" [authors' translation] (Sigaut, 1987: 10).

\section{Technology vs typology?}

Typology refers to the science of analysis and description of typical forms in a complex reality, permitting classifications to be defined. Typology can be applied to the living as well as non-living world, materials as well as non-material entities.

In its application to prehistoric archaeology, typology refers to different concepts depending on the historical context and the epistemological point of view. Typology, as a tool for classifying stone and osseous equipment, came into being in the second half of the nineteenth century with the work of G. Mortillet and his concept of "index fossil" (Groenen, 1994). Interest in the morphology of archaeological objects and their ornaments supersedes the knowledge of know-how required for their processing, and becomes the main tool for the elaboration of chrono-cultural seriations. This genealogical classification aimed to account for the real historic relationship between human groups was also applied to the study of techniques (Haudricourt, 1964) and reflects a historical or evolutionary view of the object (Haudricourt, 1968: 732).

This epistemological approach to typology long influenced research in prehistoric archaeology in France as well as other European countries. Typology remains a very useful tool for classifying archaeological objects on the basis of common formal and functional or aesthetic attributes (material, shape, size). The classification of assemblages by class, category and tool types, permits a global understanding, and thus, highlights differences or correlations in the manufacturing and consumption activities in various sites or various archaeological levels of the same site.

During the second part of twentieth century a significant paradigm shift in the recognition of the archaeological artefacts took place. Studying the "garbage" of prehistoric groups, the knapping waste, the tools used until exhaustion, the production failures became an efficient means for understanding the vast majority of archaeological objects. Thanks to the concept of chaine opératoire, archaeological and ethnographic objects have been given a real dynamic dimension. Henceforth, it is possible to transcend the shape of the tool to apprehend the know-how possessed by the studied human groups, that is to say the invisible, unobtrusive, collective unconscious part inherent within every single object (Leroi-Gourhan, 1943, 1964; Pelegrin, 1991; Lemonnier, 1993; Perlès, 2012). The concept of chaîne opératoire was used for the first time in 1964 by André Leroi-Gourhan (Inizan et al., 1999), and was subsequently formalized by ethnologists working on techniques (as Creswell, Lemonier, Haudricourt etc.), something that was to give rise in 1974 to the creation of the research laboratory (ER) 191 "Techniques et culture" and then to the scientific journal of the same name in a context of full development of "cultural technology" (Coupaye and Douny, 2013; see also Pelegrin, 1991).

The chaîne opératoire is a key analytical tool for technology studies. M. Mauss is acknowledged to be the first scholar to introduce technology into social anthropology to describe the study of the material activity of human groups, and more globally, any activity enacted through the human body (Mauss, 1947; Inizan et al., 1999). According to M. Mauss, technology is a fully-fledged discipline that we need to distinguish from economy (Haudricourt, 1968: 731). With the concept of "body techniques", that is to say any muscular custom that is socially acquired (Mauss, 1936), M. Mauss introduced the innovative idea that our daily life gestures are the result of social heritage and can therefore be identifiers of a given human group (Haudricourt, 1964). The ambition to promote technology to the rank of science in its own right is visible in the writings of Haudricourt, who defined it as a science of "productive forces", a "science of human activities". Through the human point of view in object manufacturing and use, we can understand the laws governing its emergence and its transformation (Haudricourt, 1964: 28; for a detailed discussion of the different historical and epistemological points of view concerning the analysis of technical activities, see; Haudricourt, 1968).

According to M.-L. Inizan, J. Tixier, H. Roche and their colleagues, some of the initiators of knapped stone technology studies in France, "no typology can be fully operative if it does not take techniques into at least partial account. We do not therefore consider substituting technology for typology, for they represent two distinct approaches developed to meet different ends; they can however be used concurrently, and great benefit can be derived from the comparison of the results they yield" (Inizan et al., 1999: 13).

In a recent article, Valentin (2008: 189) defends another epistemological position, where he criticizes the complementarity of typology and technology which suggests a methodological equivalence that does not actually exist, especially because very early on, the typological approach to lithic objects integrated technological criteria in addition to morphological criteria. Secondly, because according to this author typology not only amounts to a classification of tool and weaponry morphology, but must also be considered in its first etymological meaning (see above). Thus, typology as an analytical tool in prehistoric archaeology must be reconsidered to be a fully-fledged science of the analysis and description of shapes of any kind. Therefore, typology can and should be tied to the "procurement choices", the "knapping methods", the "manufacturing and use methods of tools" (Valentin, 2008: 189).

Narrowing typology to a strictly classificatory approach of equipment morphology, and thus, to a "strictly enumerative typology" contradicts the reality of archaeological research of the last decades (Valentin, 2008: 190), in the field of lithic analysis (eg: Pigeot, 1987; Valentin, 1995, 2006; Bodu, 1993; Christensen and Valentin, 2004; Klaric et al., 2009; Simonet, 2011) as well as in the field of osseous industry (Averbouh, 2000; Pétillon, 2006; Goutas, 2008). Many recent studies are now developing 
"typologies with interpretive ambition" looking for "behavioral norms" and ultimately "values", by a full integration of technological data (from acquisition of raw material to its use) (Valentin, 2008).

In that sense, the morphology of an object cannot be considered to be a simple fact but as the direct consequence of a response to a specific need (functional purpose), a life cycle (use, sharpening, repair, recycling), an action on the raw material (choice and sequencing of the used techniques), and the inherent properties of the worked materials as much as the terms of their supply. These considerations fully meet the idea that the shape of an object includes several dimensions within the society in which it was produced; dimensions that the cultural anthropologist Moussette (1984) formalized through the concept of "intentionality of the object". This author uses the following definitions:

- a technical or instrumental intentionality (what is the purpose of the object and how was it used?);

- a social intentionality (position of the object within a social system; e.g.: who used it?);

- and an ideological intentionality (values, ideological or symbolic beliefs linked to the object).

Each of these three "spheres of intentionality" may influence the interpretation of the objects based on their context of use or their position within the cultural system (Moussette, 1984). However, in prehistoric archaeology, social and ideological intentionality remains very complex to identify and often proves impossible. From the strict materiality of the object, we can give it a cultural anthropological meaning. We must necessarily place the object within a cycle of production and consumption which involves taking into account what A. Leroi-Gourhan defined as the milieu extérieur and the milieu interieur of a society. The milieu extérieur is defined by A. Leroi-Gourhan as "all which materially surrounds the human being: geologic, climatic, animal and plant environment" and the milieu interrieur such as: "what constitutes the intellectual capital ... that is, an extremely complex bath of mental traditions" [authors' translation] (Leroi-Gourhan, 1945-1973: 333).

In this article, we will focus on the different ways involved in the manufacturing of objects as markers of technical traditions. To be able to identify cultural choices via the technological approach, it first necessary, to assess the possible influence of determinism in order to distinguish what is, for example, the constraint of the physical properties of materials and what connects them with real cultural choices. Thus, we will discuss the dissemination of the techniques and the social interaction (Inizan et al., 1999).

\section{From the technical fact to the cultural tradition}

According to Inizan and collaborators, any production is governed by a "project" that we can apprehend through the reconstruction of chaînes opératoires, knowing that the project of a knapper or a craftsman reflects the culture in which he or she grew up. The project is defined as a conceptual scheme implemented on an operative scheme, that is to say, a sequence of operations that permits the sought objective to be achieved. Effective implementation of the conceptual scheme and the operating scheme requires tools, materials, gestures, knowledge and know-how (Inizan et al., 1999: 15).

Knowledge and know-how are two concepts clearly defined by J. Pelegrin (see Pelegrin, 1991, 1995, 2004; Inizan et al., 1999). “As knowledge can be classed the mental representations of forms and materials (concepts), and a register of action modalities (brief gesture sequences associated to their practical result). Referring to the memorizations and mental representations of objects and of facts, this knowledge ensues from a memory that is explicit and declarative in nature" (Pelegrin, 1990: 118).

The know-how refers to the ability of an individual to carry out mental operations and anticipates the results of these operations (Pelegrin, 1991: 4). "Within 'know-how', we may distinguish between an 'ideatory' time (evaluation, reflexion, decisions) and a motor time (programming and execution of the gesture)" (Pelegrin, 1990: 118). The knowledge is achieved orally and can be thus acquired over a short time through a simple observation and imitation; in contrast, know-how (the mastered ways to implement the knowledge) is achieved through the experience and involves a learning process which may be taken a long time depending on the complexity of the technical gestures involved. It is thus possible to have some knowledge (theoretical knowledge) but without the ability to implement it (Perlès, 2012: 587; Pelegrin, 1991). For instance a decoration or a shape can be reproduced without implying any real social interaction and without intent to preserve the ideological or social intentionality (sensu Moussette) initially involved in the object. Their "high visibility" makes these easily reproducible (Perlès, 2012). This question will be illustrated in our article via the example of split-based points of the Early Aurignacian. These particular productions require knowledge and complex know-how, and thus, are relevant objects for discussing the spread of ideas and the interaction between various human groups. While it is easy to mimic a shape or a symbol by simple observation without any real interaction, to reproduce a complex technique, for a very specific production target, is impossible to achieve with only a simple observation; true reproduction of a technique necessarily involves a learning phase (Inizan et al., 1999; Pigeot, 1987; Ploux, 1989) which implies a real interaction between groups or individuals (Perlès, 2012).

As emphasized by C. Perlès, since no human being or human group lives in isolation, it becomes more complex to highlight interaction networks in prehistory (Perlès, 2012). If the interactions within a restricted community are easily identifiable in the terms of the homogeneity of the practices identified at a given site, how can we pick out larger-scale interactions (via temporary or permanent movements of individuals or groups) without considering the movements of objects and diffusion of ideas: symbols, knowledge, and know-how (Perlès, 2012: 585)?

The sociological interactions allowing the diffusion of objects and ideas will also be varied(e.g. individuals moving between groups as part of marriage-like formations; exchange of objects ...) (Choyke, 1987, 2006, 2009) or by sporadic contact during seasonal activities by groups belonging to the same culture but occupying different territories. The Isturitz cave, which will be discussed further, is one of the most interesting examples in this regard. Located at a strategic crossroad between Aquitaine, the Pyrenees and Cantabria, the site seems to have been used in various Upper Palaeolithic periods, as an "aggregation site" (see Conkey, 1988; Lacarrère et al., 2011). These gatherings led to trade and to common activities. For the Gravettian of Isturitz cave, bison hunting in autumn (matriarchal herd) (Lacarrière et al., 2011) and the realization of important activities around the working of osseous materials (Goutas and Lacarrière, 2013) should be mentioned.

These interactions in the Palaeolithic are moreover well known through the studies of shell ornament circulation (Alvárez Fernández, 2001; Taborin, 2004; Bar-Yosef-Mayer, 2005), knapped stone tools, and related materials (Féblot-Augustins 1997). For these ancient times, and unlike the Neolithic, whether we consider the direct supply to sources or circulation by direct exchange or hand to hand barter, all the available data shows that "it is never organized distribution networks operating in the long term and relying on specialized producers ( ... )" [authors' translation] (Perlès, 2012: 580). The ethnographic data on hunter-gatherers 
shows, moreover, that in such band-level societies, the exchange of raw materials or tools is always quantitatively restricted; the groups stock, especially on the occasion of targeted expeditions (Féblot-Augustins and Perlès, 1992).

\section{Technology as a way to reassess the relevance of old collections}

As analysts of the manufacturing techniques used to produce worked osseous materials, researchers are still largely dependent on old collections consisting mainly of finished objects. This is due in part to selection of the materials by previous scholars. Although research on the Early Upper Palaeolithic has expanded in recent years and benefited from new excavations with new techniques, but the latter have not yielded enough remains to renew the osseous industry data available for these periods.

To assess the relevance of these old assemblages and to therefore fully incorporate osseous industries into the debate on the characterization of the material culture of the Aurignacian and Gravettian periods, it is imperative to find a way to obtain as much information as possible from available collections. We will see the extent to which osseous technology may help overcome certain problems connected to old excavation methodology, less rigorous than what is encountered today. Although it is now a standard approach in the teaching of French prehistory (for Palaeolithic assemblages: Averbouh, 2000; Vanhaeren, 2002; Goutas, 2004; Christensen and Chollet, 2005; Pétillon, 2006; Tartar, 2009; Rémy, 2013; Malgarini, 2014), it still represents a new approach in Spain (Tejero, 2010) and in some other countries (White, 2007).

Typology, in its most common sense in archaeology (descriptive typology sensu Valentin) is a very useful tool in classification: it creates links between objects on the basis of common formal and functional or aesthetic attributes. However, typology in this restricted meaning, does not offer the same possibilities as the "analytical and interpretative typology" (Valentin, 2008). Alone, it does not permit us to grasp what might be called the hidden meaning of archaeological artefacts. Manufacturing tools involves various kinds of know-how involving multiple actions and technical operations organized in particular sequences (Averbouh, 2001); some are reproduced consciously and others unconsciously. Differences or similarities in producing of tools and weapons are thus essential elements in establishing chronocultural characterization (Goutas, 2009; Tejero and Grimaldi, 2015; see also Averbouh, Goutas, Marquebielle, this volume). Technology can identify stratigraphic inconsistencies that typology alone most often cannot.

For example, by observing complementarities in terms of raw materials, technical stigmata and fracture surfaces, one can look for fits between objects from different layers, as has been classically applied in lithic technology. However, as developed by A. Averbouh (2000), "refitting by default method" (remontage par défaut) can also be employed. This second method was inspired by the mental refitting method used in stone technology (Tixier, 1980; Pigeot, 1987; Inizan et al., 1999) which permits researchers to identify consistencies and inconsistencies within the chaîne opératoire and, thus, check the reliability of the studied series.

The "refitting by default method" looks for links in shape, raw material and technique between waste, blanks and finished objects. Let us consider, for example, two distinct archaeological layers. The first has yielded finished tools and the second has yielded some waste products entirely consistent with the production of these same tools. This technical and economical complementarity may reflect stratigraphic inconsistencies. Now consider two different cultural layers containing the same types of hunting weapons. On the one hand, this typological similarity may be the result of a tradition which continued over time or just a cultural convergence. But it is also possible that the hunting weapons are intrusive in one of the two layers.

Because of the impossibility of actually physically refitting worked osseous materials in technology studies, it is important to base analyses on the repetition of several refittings by default in order to check the reliability of the approach. Moreover, the greater the number of objects, the more accurate the results we will have, especially if all technical categories are represented and well preserved (waste, blanks and tools). However, due to the differential preservation of osseous materials, fragmentation rate, major transformation of objects and scarcity of waste, it is often sequences or phases that are found rather than complete patterns of manufacturing (Averbouh, 2000).

\subsection{Reassignment of projectile points to their original levels: the Gravettian of the Isturitz cave}

The projectile points of the Isturitz cave, in Southern France (Pyrénées-Atlantique) (Fig. 1) may be characterized by the knowhow that was needed for this particular kind of manufacturing practice. In other words, the technological approach (Goutas, 2004:106-117) proved an effective way of studying this artefact assemblage.

From the beginning of the twentieth century to the 1950s, Emile Passemard and then René and Suzanne de Saint-Périer carried out important excavations at Isturitz Cave (Passemard, 1944; SaintPérier and Saint-Périer, 1952). These excavations yielded the most important French assemblages of prehistoric osseous materials, both in terms of numbers and the great variety of objects unearthed, and by the number of "cultures" identified in the stratigraphic sequence: mainly ranging from the Aurignacian to the Magdalenian. The intensity of these excavations unfortunately led to the total destruction of the archaeological levels within the main enclosed space within the cave ("Grande salle"). The "Saint-Martin room", where the human occupation was more restricted, still preserves archaeological levels in situ. These levels are connected to the Aurignacian and were excavated in the 2000s under the direction of Christian Normand (Normand and Turq, 2007; Normand et al., 2013).

Thanks to the technological analysis conducted by one of the authors (N. G.) on the worked osseous material from this site, it proved possible to reassign projectile points to their level of origin. Gravettian and Solutrean layers contained exactly the same type of bevelled points (Fig. 2). These points were very striking as they are made from the long bone diaphysis of large mammals and are often massive. Their bevel was created by a deep abrasion and associated with a rough striation.

Although these points were significantly more numerous in the Gravettian layer, the working of the raw material, the manufacture of these points, their size, and their cross-section led us to reject their Gravettian attribution and to regard them as strictly Solutrean. This hypothesis was corroborated by a literature review, since this kind of point has been reported on other Solutrean sites such as Laugerie-Haute or the 'Grotte des Harpons' (Passemard, 1944; Saint-Perier, 1952; Mújika, 1991; Knecht, 1991). Moreover, as far as the Gravettian assemblages of the Isturitz Cave are concerned, these points are almost exclusively associated with the excavations of R. and S. de Saint-Périer with very few coming from the excavations of E. Passemard. This anomalous distribution of points seems to reflect a misreading of the stratigraphy by R. \& S. de Saint-Périer, a misreading aided by stratigraphic disturbances which have affected the archaeological layers (Goutas, 2004). 


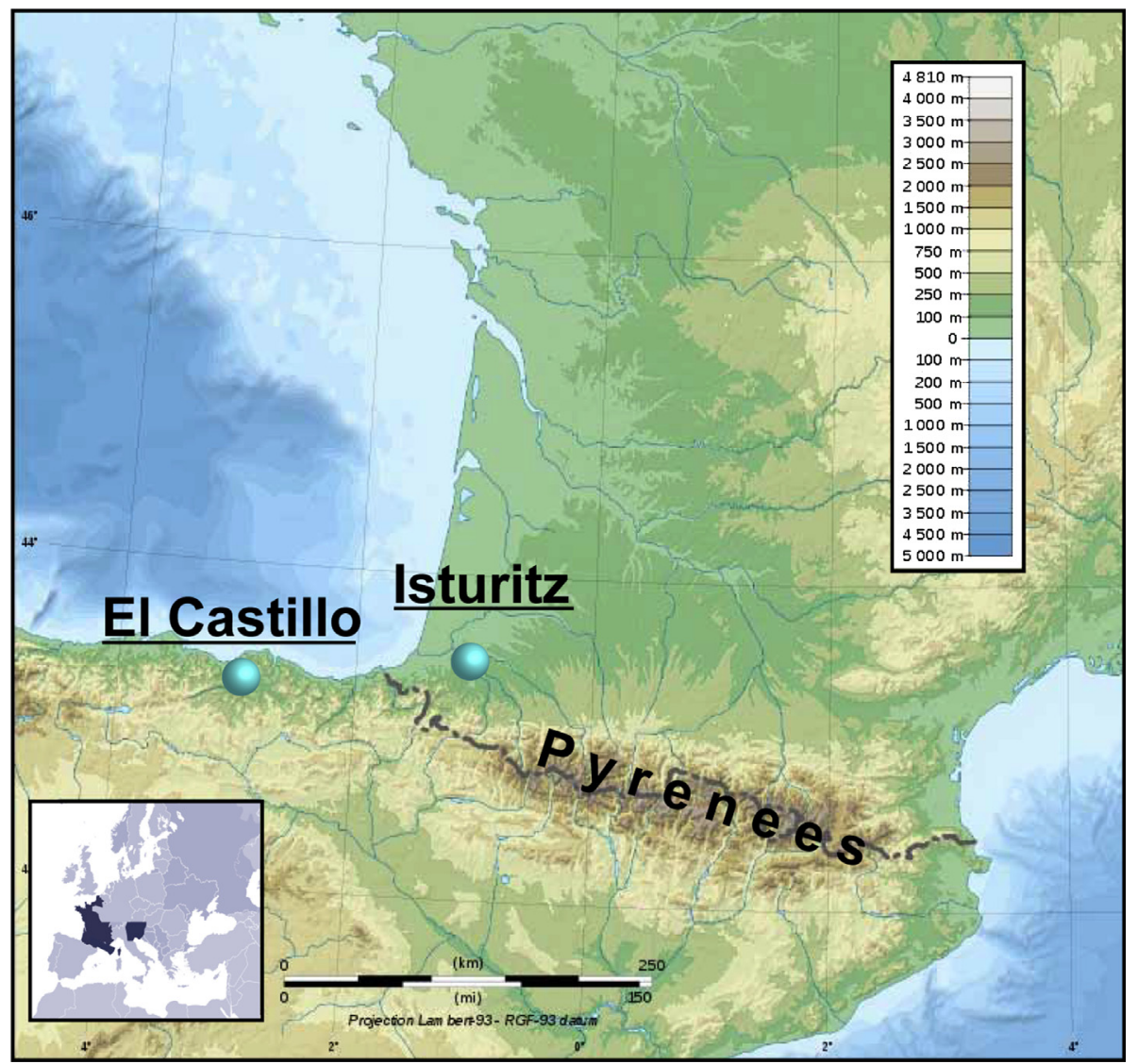

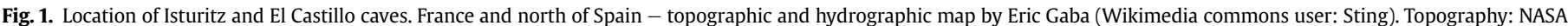
SRTMBO. Bathymetry: NGDC ETOPO1. Additional data: NGDC World Data Bank II. Europe map by mapsof.net.
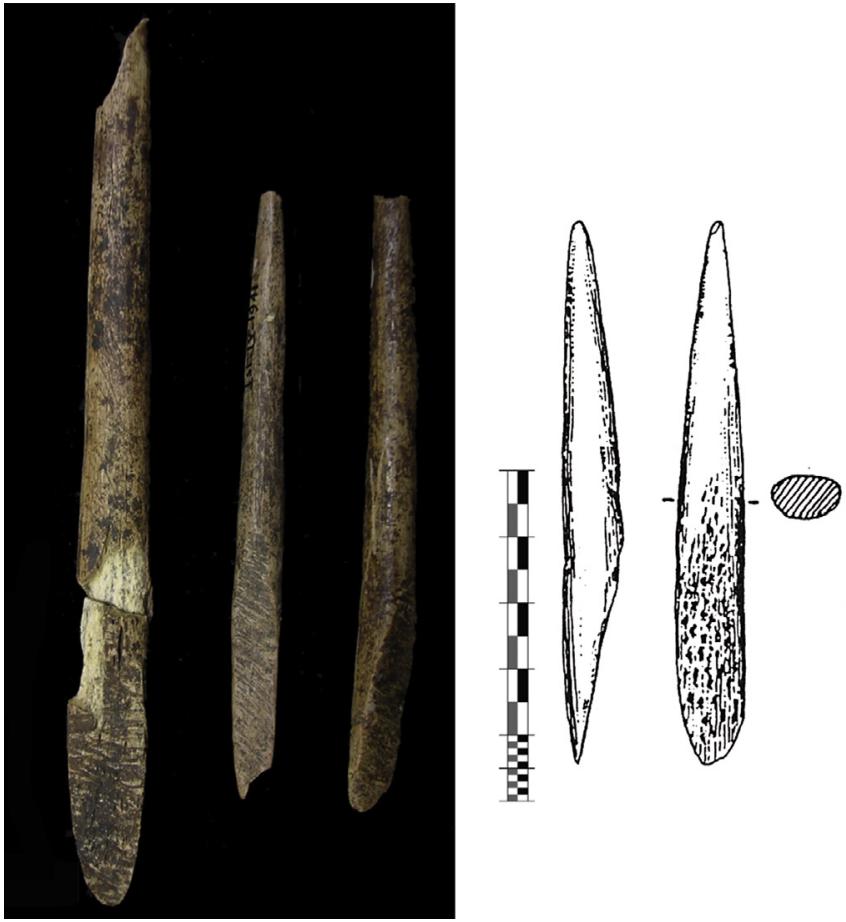

Fig. 2. Bevelled bone points: on the left from Isturitz cave (Upper Gravettian layer, III, photographs by N. Goutas) and on the right from Laugerie-Haute ("Aurignacien V" or "Proto-Solutrean", after Knecht, 1991, Fig. 1-d: 45).

\subsection{El Castillo Cave: assessing osseous industry from Obermaier's excavations}

Concerning the representativeness of the series from earlier excavations, there is another example from the Aurignacian levels of El Castillo cave (Puente Viesgo, Cantabria). This site, located in Northern Spain, is one of the most important European Palaeolithic sites (cf. Fig. 1). It was excavated between 1910 and 1914 by $\mathrm{H}$. Obermaier. V. Cabrera and F. Bernaldo de Quirós have resumed archaeological work at El Castillo cave since 1980 to the present (Cabrera, 1984; Cabrera et al., 2002). During the initial technoeconomic analysis conducted by one the authors (J.-M.T.), the entire osseous industry of the Obermaier excavations was numerically small - about 30 pieces - and exclusively composed of technologically finished objects (Fig. 3). This set has been mentioned in several publications focusing on typology, based upon the presence of split-based points, mainly for confirming the assignment of these levels to the early phases of the Aurignacian. Nevertheless, one cannot solely reason on the basis of the presence/ absence of pieces considered "index fossils". First, "index fossils" in osseous industry were identified only on the basis of their gross morphological characteristics, influenced by traditions in lithic analysis. Secondly, the "index fossils" were identified in contexts in which they were not expected. The Isturitz points are known nowadays in other Gravettian phases and no longer only in association with the Noaillian phase (Goutas, 2008, 2013a).

Concerning El Castillo, several hypotheses exist to explain both the rarity of these finds there and, at the same time, the presence there of only finished objects. From a quantitative point of view, the scarcity of these finds at El Castillo could be the result of: 1) 


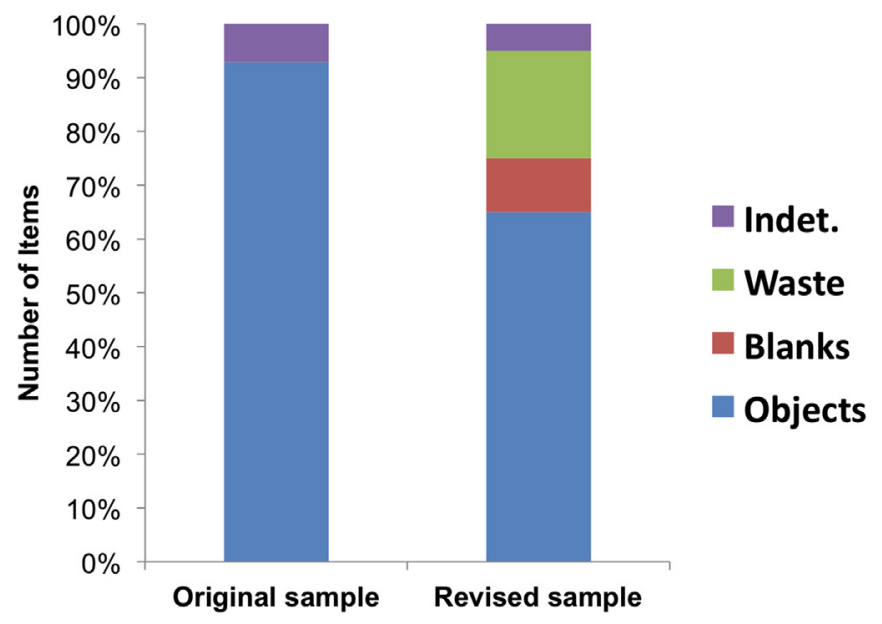

Fig. 3. El Castillo (Layer Delta of Obermaier excavations): techno-typological composition of the original sample compared to that of the sample after the faunal remains revision.

differential preservation of organic material; 2) a selection of the finds by early excavators; 3 ) or may relate to the site function in which manufacturing osseous materials would have been limited. The exclusive presence of finished objects may be the result of introducing objects already manufactured elsewhere to the site. Waste products would have been left at some other site where the actual production took place, or at another location on the site, not still identified (Tejero, 2010, 2013).

Technological analysis can now answer these questions. Thus, it appears that the limited number of pieces of worked osseous materials:

1. is not the result of poor preservation of organic material since faunal remains are numerous and well preserved. The surface condition of the objects in the worked osseous material is quite good (Dari, 2003; Liouville, 2007; Tejero et al., 2010).

2. The absence of worked osseous finds is most probably linked to the extensive and imprecise methods used by Obermaier during his excavations (Cabrera, 1984). In most archaeological assemblages, the worked osseous sample is exclusively composed of identifiable objects when no worked osseous technology specialist is part of the research team during excavation (see for instance Tejero, 2013 for the Spanish Aurignacian levels of El Castillo but also for the sites of Conde, Cierro and Covalejos; and Tejero and Grimaldi, 2015 for the Aurignacian layers of Riparo Mochi. Italy). A new analysis of the faunal remains from Obermaier's excavations at El Castillo, now held in the Museo de Prehistoria y Arqueología de Cantabria (Santander), has confirmed the hypothesis that a selection of the identifiable objects has been made during the Obermaier's excavations, while the "technical pieces", like blanks or wastes, were not identified. As expected, we recovered a quantity of new objects representing a $40 \%$ increase in the sample and, most of all, this extra effort produced a qualitatively important sample (Fig. 3). While only large characteristic objects were collected by Obermaier and his collaborators, a much more diversified selection of objects could be added to the assemblage (waste products, blanks) permitting us to reconstruct the operational sequence of antler working at this site.

3. The ubiquity of finished objects in earlier excavations has also been reassessed through technological analysis since some pieces considered then to be finished objects are actually blanks.

4. The technological study of these newly discovered blanks and waste shows that contrary to the initial suggested hypothesis, a worked osseous production took place on site. Moreover, these newly found pieces permit us to characterize Aurignacian blank production (debitage) thanks to a technological and experimental analysis (Tejero et al., 2012).

Ultimately, these two examples from Isturitz and El Castillo Caves demonstrate the importance of the technological approach for objectively assessing the integrity of archaeological assemblages and whether they can offer reliable interpretive models.

\section{Technology as a useful method to characterize regional and paleoethnographic features of Aurignacian split-based points}

Choice of materials, choice of techniques and their particular articulation within a specific production and consumption process provide valuable data on the collective or individual representations (knowledge and know-how) involved in the processing of raw materials, which in turn are determined by social traditions (see above). Sharing the same know-how between two human groups implies necessary stabile social relations between them. That is why studying the technology provides a relevant way to explore interregional cultural differentiation both synchronically and diachronically (Goutas, 2009, 2013c).

Regionally, the French and Spanish Pyrenees offer an interesting area of study because on both sides of this natural mountain barrier, Aurignacian groups maintained very close ties with each other over long distances. This well-known cultural permeability, expressed in the stone industry (origin of raw material, knapping and shaping techniques used, equipment) is also well known for the worked osseous industries (Arrizabalaga, 2007; Normand and Turq, 2007; Tejero, 2010, 2013; Lacarrière et al., 2011; Soulier et al., 2014).

To illustrate this issue we will focus on the split-based points. These points are one of the most characteristic Aurignacian "morphotypes" (Knecht, 1991, 1997; Liolios, 1999, 2006; Tejero, 2014, in press). They have been used to establish the periodization of the Aurignacian. The internal organization of this technocomplex simultaneously relied on quantitative representation of lithic types and on the nature of the osseous points, sometimes prioritizing the latter over the former (Peyrony, 1933, 1934). The traditional view of the Aurignacian as the first "culture" of the Upper Palaeolithic associated with expansion of modern H. sapiens expansion across Europe and archaeologically defined by the association of a particular assemblage of stone tools (end scrapers, Aurignacian blades, etc) and, in particular, antler tools (namely split-based points) has led to the formulation of models advocating that there was techno-complex homogeneity (e.g., Mellars, 1989, 2004). However, recent studies of lithic technology from early Upper Paleolithic sites in various geographical areas have improved our knowledge and changed our perceptions of the Aurignacian as a homogeneous entity over all its duration (e.g., Bon, 2002, 2006; Bon et al., 2002; Teyssandier, 2007, 2008; Teyssandier et al., 2010). The study of the bone and antler industry has made us re-evaluate the concept of a homogenous early Aurignacian. D. Liolios (1999) has demonstrated the existence of different concepts in morphometric designs in the apparently monotonous corpus of split-based points from several French and Central European sites. Other technical aspects of these points, for instance, alternative ways of manufacturing spear point bases (Henri-Martin, 1930; Peyrony, 1935; Nuzhnyi, 1998; Tartar and White, 2013; Tejero, 2014) look also heterogeneous if we review in detail the European archaeological record from a technical and functional perspective.

Split-based points, by their shape and their very particular hafting system, demonstrate the existence of a strong and unitary concept at an European scale. Can we say that this unity of form is 
also found in the ways these points were manufactured? Are there collective representations shared by several regional groups or conversely are there elements of differentiation that a typological approach alone cannot identify? Our research on worked osseous materials from French and Spanish Aurignacian sites enables us to bring new elements to the discussion of this question.

Traditions of shaping these kinds of points turn out not to be identical across regions. In the French Pyrenean region, in Isturitz Cave, the studies of D. Liolios (1999) and our own research (Goutas, 2005; Tejero, 2014) have documented the systematic presence of a regular and flattened surface on both sides of the split base. Our own observations show that this technical attribute is obtained by scraping or abrasion (Goutas, 2003a, 2005, in press), or by splitting as suggested by D. Liolios (Fig. 4 and Fig. $5 n^{\circ} 1, n^{\circ} 2$ ). According to Knecht (1991), this preparation creating two flattened surfaces on both edges of the split-based point would be used to control the propagation of the fracture wave during cleavage of the base to minimize the risk of breakage. The cleavage of the base is a very important moment in the manufacturing process because if the point breaks at this stage in the operational sequence it is necessary to completely reshape the point (Knecht, 1991; Liolios, 1999). This hypothesis fits well with what was observed of the manufacturing technique for bases on points from the assemblage from the new excavations of Isturitz (Goutas, 2005) but also on points from Spanish assemblages where exactly the same kind of attribute has been identified (Tejero, 2013, 2014) (Fig. $5 \mathrm{n}^{\circ} 3$ ). In most cases, the spread of the slot on the proximal end of split based points stops just a few millimetres before the end of the lateral flattening (Tejero, 2013).

This way of preparing the base was until recently known only from the Isturitz Cave. It has now been identified by one of the authors at another French site, Abri Poisson (Dordogne) and also at the Spanish sites of El Castillo and Covalejos (Cantabria) (Tejero, 2014) (Fig. 4). These new data underscore once more the permeability of natural boundaries in terms of technical traditions during the Aurignacian. This type of technical attribute, beyond its technological interest, takes on an important cultural and historical dimension. Human groups living in the region of Aquitaine and Cantabria must necessarily have been close to share a community of thought going beyond the "general of split based point concept", a closeness which expressed itself even in manufacturing details.

\section{Technology is also a way to understand chronological seriation}

Chronological seriations have usually been based on the typological composition of archaeological assemblages, particularly for Palaeolithic materials. However, detailed study of technology also provides us with different options of social interpretation. Because working procedures on osseous raw materials offer a wide range of possible solutions, the solutions adopted by different human groups, based on various technical, economic, social or symbolic contingences provide us with an indication about the cultural identity of their makers. These choices are sometimes specific to particular chrono-cultural contexts and can therefore be used as objective criteria for diachronic differentiation. On the other hand, processing methods of osseous materials (eg. extraction, fracturing, bipartition etc.) are not very diversified, as well as elementary techniques allowing their implementation (eg. sawing, grooving, direct percussion, scraping etc.). On the contrary, the possible combinations allowed by the association of these techniques (the "procedures" sensu Averbouh, 2000) to achieve a particular purpose (transformation of a block and/or production of objects) are extremely varied.

The example of rod production from antler is also pertinent here. Different processes were in use during Aurignacian and Gravettian (Liolios, 1999; Goutas, 2003a, 2003b, 2009, 2013b;
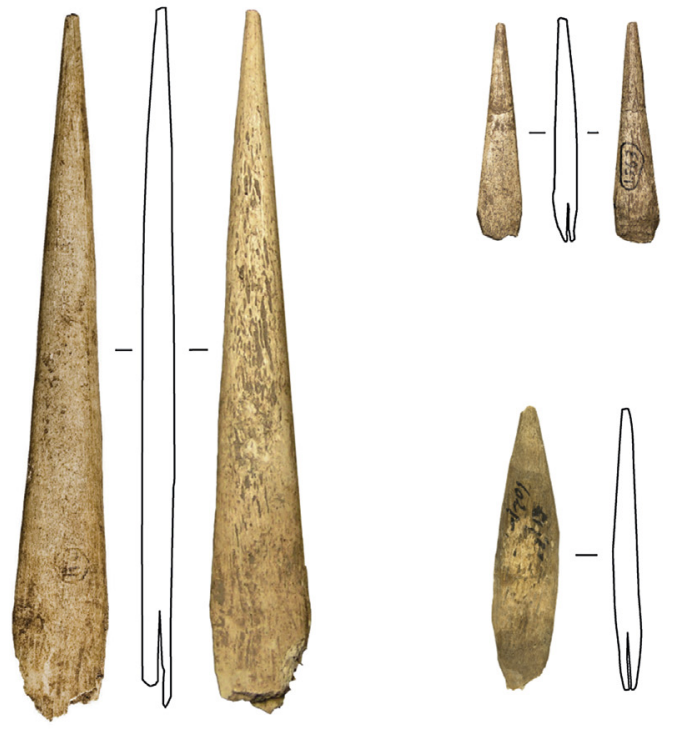

mhin

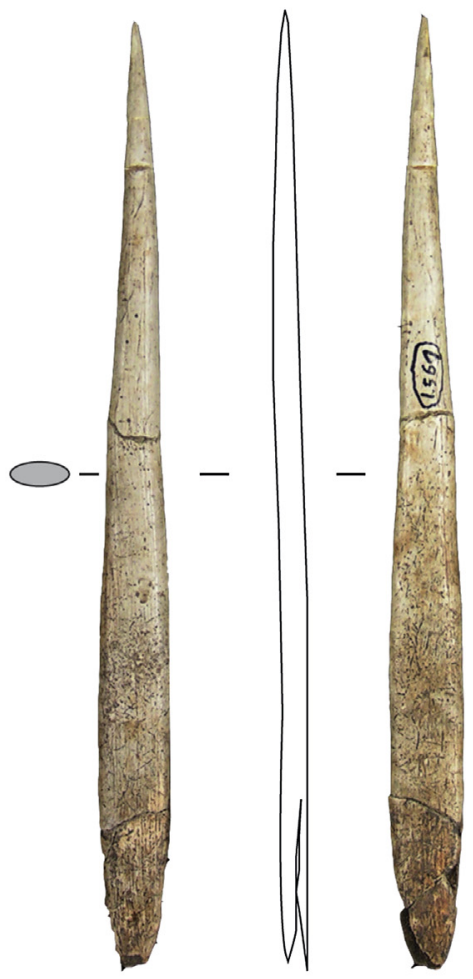

Fig. 4. Main antler objects (split-based points) of El Castillo cave: Obermaier's excavations sample. 


\section{1) Isturitz cave (old excavations)}

Blank

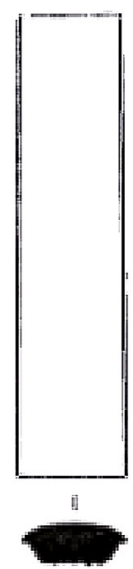

Preform

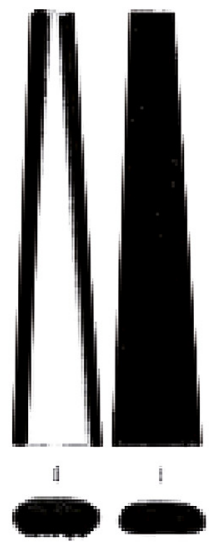

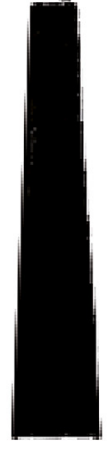

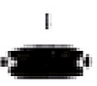

Lateral flattening of the proximal end: by splitting (Liolios, 1999, see above) or by scraping/abrasion (Goutas, 2003; Tejero, 2010)

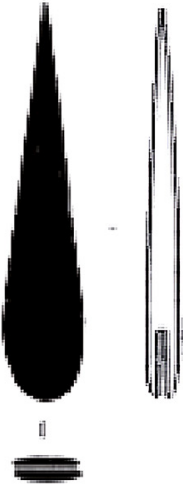

Shaping of the base and set to the axis of the point

\section{2) Isturitz cave (new excavations)}

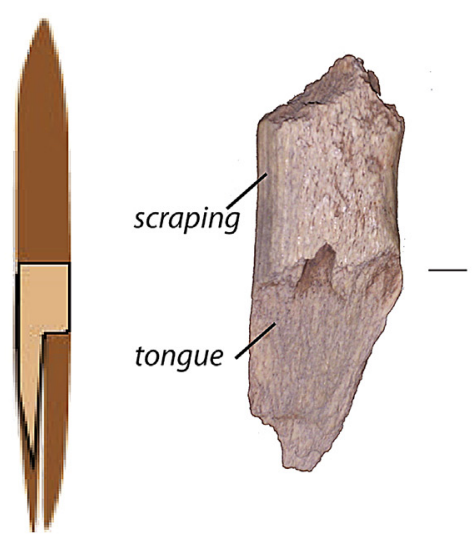

lower face

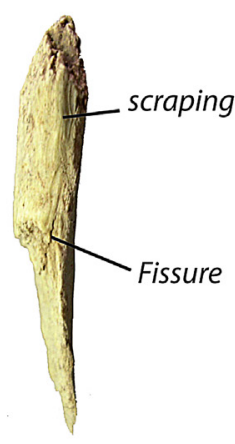

profile

\section{3) Covalejos cave}

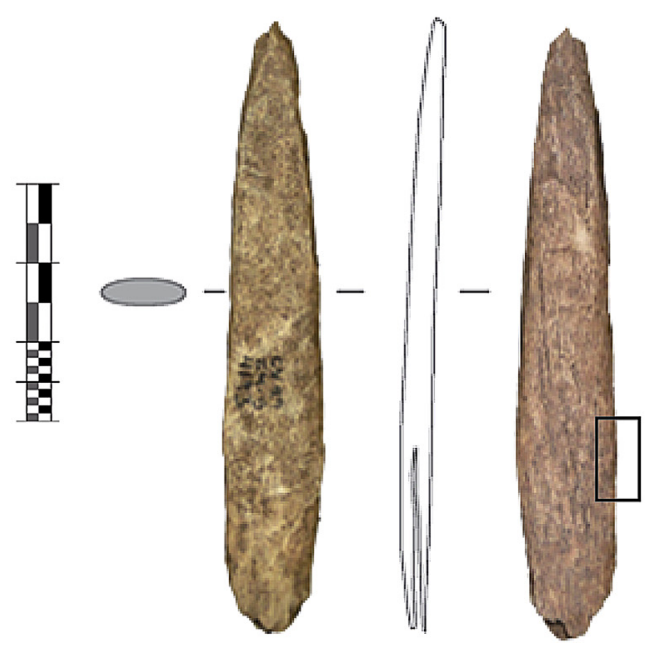

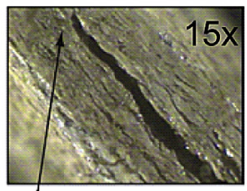

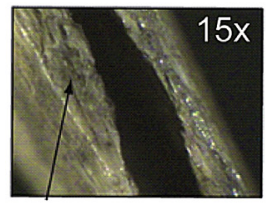

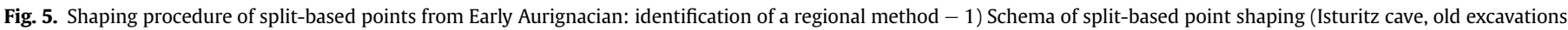

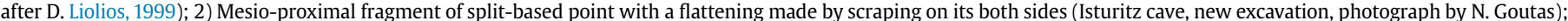
3) Split-based point with a flattening made by scraping of both sides of the proximal part (Covalejos cave, Cantabria, Spain, photographs by J.-M. Tejero).

Tejero, 2013, 2014). The identification and characterization of these specific processes may also represent valuable elements in chronological seriation.

During the Aurignacian, the longitudinal splitting of antler ("débitage par refend", Liolios, 1999), designed to produce rods for manufacturing projectile points, was identified during the analysis of a few French and Central Europe collections (Knecht, 1991; Liolios, 1999). Recently, one of the authors, along with other colleagues, has characterized this process following a technological and experimental study of Spanish assemblages (see above Tejero et al., 2012). Debitage by splitting was carried out on already segmented antler beams without preparation of the secondary blocks. This technical procedure from the Aurignacian was also identified in a Gravettian context but the objectives were very different since during Gravettian, this procedure was only used for making domestic tools while during Aurignacian it is specifically used for producing hunting weapons (Goutas, 2003b, 2004, 2009).

During the Gravettian, the splitting procedure is used in conjunction with another procedure, known as the "groove and splinter technique", called in French "double rainurage longitudinal" that can be translated as "double longitudinal grooving procedure (DGP)". This second procedure is the only one used for manufacturing hunting tools during the Gravettian. However, this technological mixing does not stop here: a third procedure was also used: the "grooving/splitting procedure" (Fig. 6). On a few Gravettian sites, the surface is very sketchily prepared by grooving on one or two sides of the secondary blocks. It was used during the splitting process in order to guide the propagation of the fissure and, thus, better control the blank width. The expected blank has to be large because they were also used to make massive tools. It is 


\section{Rod extraction by :}

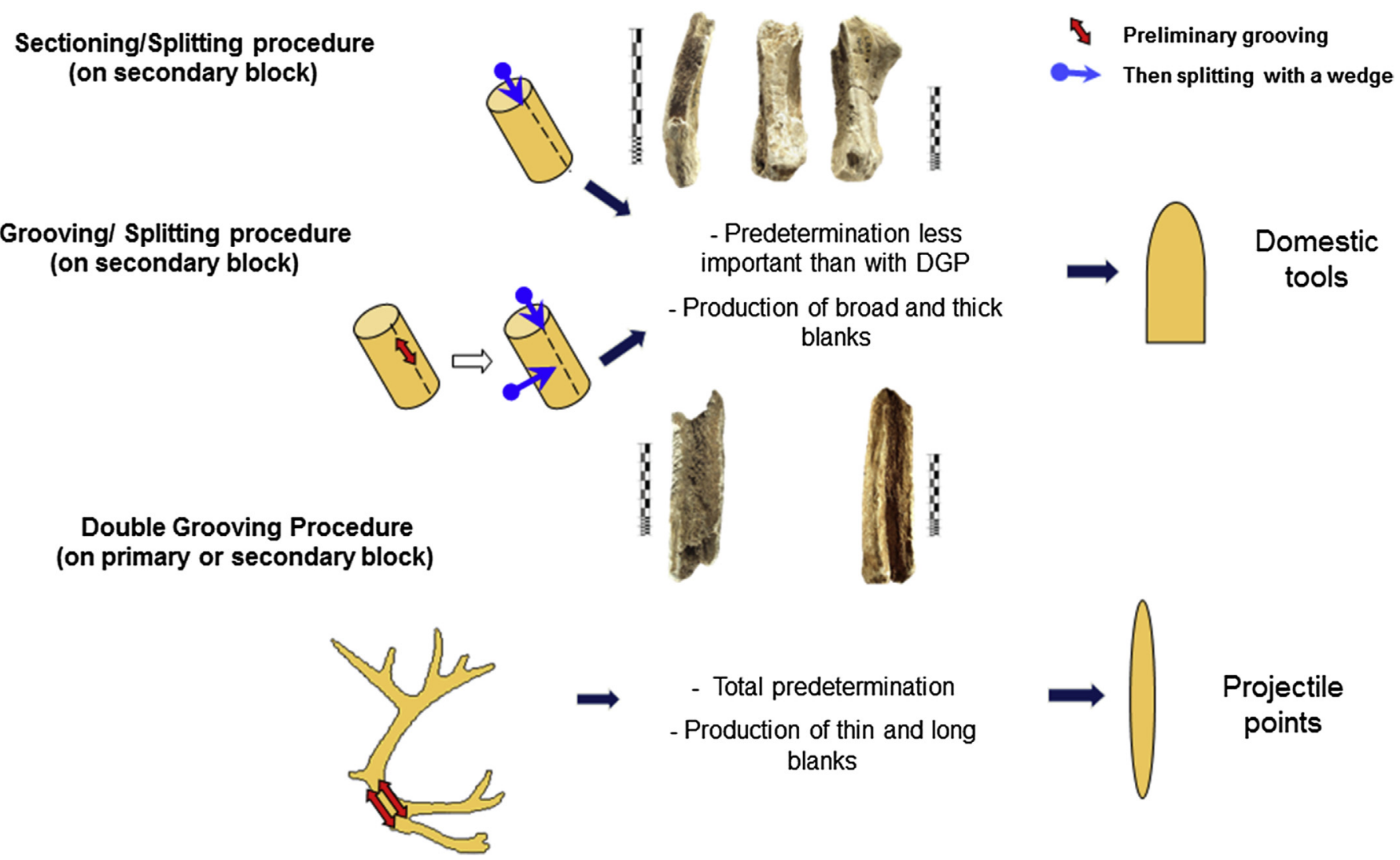

Fig. 6. Three debitage procedures used during the Gravettian in France for the rods production (after Goutas, 2003, 2004).

now clear that osseous technology allows us to demonstrate unexpected links between Aurignacian and Gravettian material culture, and simultaneously helps shed light on particular chronocultural elements, given the similarity of the technical approaches in both periods although Aurignacians and Gravettians were not aiming at the same production goals.

\section{Conclusion}

The examples of technical procedures demonstrate how research on processing methods for worked osseous materials have great potential for thinking about Palaeohistory and increasing what is known about life in the European Palaeolithic. What interests us in the end, is the "hidden meaning" behind the way these techniques either change or remain stable and permanent in terms of the economic, the social or symbolic choices people made when creating the objects they made. When possible, this type of approach should be integrated into interdisciplinary research taking into account other spheres of activity. Of course, the study of technical processes will not answer all questions in just the same way that study of typology should not be considered a way of explaining everything about life in the past. This simplistic and caricatured academic discourse is not one we have chosen to follow although it is obvious that both approaches are necessary. In this paper, we wish to show the way the technological approach can enable us to think about social fact, beyond simple description of the technical facts.

\section{Acknowledgements}

We thank Catherine Schwab for providing us access to the worked osseous collection of the Isturitz cave held in the Museum of Saint-Germain-en Laye and Christian Normand and Joëlle Darricau for giving one of the authors (NG) to study the worked osseous materials from the recent excavation at the Isturitz cave. We also thank Alice Choyke, Françoise Audouze and Yann-Axel Gomez-Coutouly for their useful reading and comments on this paper. Any errors, however, are our own responsibility.

This paper is part of the HAR2014-55131 research projects of the MICINN and the Quality Research Group of the Generalitat de Catalunya SGR2014-108. J.-M Tejero's research has been supported by a Beatriu de Pinós grant co-funded by the Catalan Government and European Community via the Marie Curie Actions of 7th Framework Program for Research and Technological Development.

\section{References}

Álvarez Fernández, E., 2001. L'axe Rïn-Rhône au Paléolithique supérieur récent: l'exemple des mollusques utilisés comme objets de parure. L'Anthropologie $105,547-564$

Arrizabalaga, A, 2007. Frontières naturelles, administratives et épistemologiques. L'Unité d'analyse dans l'archéologie du Paléolithique (dans le cas basque). In: Cazals, N., et al. (Eds.), Frontières naturelles et frontières culturelles dans les Pyrénées préhistoriques. Ediciones Universidad de Cantabria, Santander, pp. 27-38.

Averbouh, A., 2000. Technologie de la matière osseuse travaillée et implications palethnologiques. L'exemple des chaines d'explotation du bois de cérvide chez 
les Magdaléniens des Pyrénées. Ph.D. Thesis. Université Paris I Panthéon-Sorbonne, Paris.

Averbouh, A., 2001. Methodological specifics of the techno-economic analysis of worked bone and antler: mental refitting and methods of application. In: Choyke, A., Bartosiewicz, L. (Eds.), Crafting Bone: Skeletal Technologies through Time and Space - Proceedings of the 2nd Meeting of the (ICAZ) Worked Bone Research Group Budapest, 31 August - 5 September 1999. British Archaeological Reports International Series 937, Oxford, pp. 111-121.

Bar-Yosef Mayer, D., 2005. The exploitation of shells as beads in the Paleolithic and Neolithic of the Levant. Paléorient 31 (1), 176-185.

Bodu, P., 1993. Analyse techno-typologique du matériel lithique de quelques unités du site magdalénien de Pincevent (Seine-et-Marne). Applications spatiales, économiques et sociales. Ph.D. Thesis. Paris 1 Panthéon-Sorbonne University, Paris.

Bon, F., 2002. Les termes de l'Aurignacien. In: Bon, F., et al. (Eds.), Actas de la Mesa redonda celebrada en Toulouse entre los días 27 de febrero y 1 de marzo de 2003: Autour des concepts de protoaurignacien, d'Aurignacien archaïque, initial et ancien. Unité et variabilité des comportements techniques des premiers groupes d'hommes modernes dans le Sud de la France et le Nord de l'Espagne. Espacio, Tiempo y Forma, Serie I Prehistoria y Arqueología 15. UNED, Madrid, pp. 39-65.

Bon, F., 2006. A brief overview of Aurignacian cultures in the context of the industries of the transition from the Middle to Upper Paleolithic. In: Bar-Yosef, O., Zilhão, J. (Eds.), Towards a Definition of the Aurignacian : Proceedings of the Symposium Held in Lisbon, Portugal, June 25-30, 2002, Trabalhos de arqueologia, vol. 45, pp. 133-144.

Bon, F., Maíllo, J.M., Ortega, D. (Eds.), 2002. Actas de la Mesa redonda celebrada en Toulouse entre los días 27 de febrero y 1 de marzo de 2003: Autour des concepts de protoaurignacien, d'Aurignacien archaïque, initial et ancien. Unité et variabilité des comportements techniques des premiers groupes d'hommes modernes dans le Sud de la France et le Nord de l'Espagne. Espacio, Tiempo y Forma, Serie I Prehistoria y Arqueología 15. UNED, Madrid, pp. 39-65.

Cabrera, V., 1984. El yacimiento de La Cueva de "El Castillo": Puente Viesgo, Santander. Instituto Español de Prehistoria, Consejo Superior de Investigaciones Científicas, Madrid.

Cabrera, V., Bernaldo De Quirós, F., Maíllo, J.M., Valladas, H., Lloret, M., 2002. El Auriñaciense arcaico de El Castillo (Cantabria): descripción tecnológica y objetivos de la producción. In: Bon, F., et al. (Eds.), Espacio, Tiempo y Forma, Serie I Prehistoria y Arqueología 15. Actas de la Mesa redonda celebrada en Toulouse entre los días 27 de febrero y 1 de marzo de 2003: Autour des concepts de protoaurignacien, d'Aurignacien archaïque, initial et ancien. Unité et variabilité des comportements techniques des premiers groupes d'hommes modernes dans le Sud de la France et le Nord de l'Espagne. UNED, Madrid, pp. 67-86.

Choyke, A., 1987. The exploitation of red deer in the Hungarian Bronze Age. Archaeozoologica 114-115.

Choyke, A., 2006. Bone tools for a lifetime: experience and belonging. In: Astruc, L., Bon, F., Léa, V., Milcent, P.-Y., Philibert, S. (Eds.), Normes techniques et pratiques sociales. De la simplicité des outillages pré- et protohistoriques, $\mathrm{XXVI}^{\mathrm{e}}$ rencontres internationales d'archéologie et d'histoire d'Antibes, vol. 2006. APDCA, Antibes, pp. 49-60.

Choyke, A., 2009. Grandmother's Awl: Individual and collective memory through material culture. In: Barbiera, I., Choyke, A.M., Rasson, J.A. (Eds.), Materializing Memory: Archaeological Material Culture and the Semantics of the Past, NKA, pp. $21-40$.

Christensen, M., Valentin, B., 2004. Armatures de projectiles et outils : de la production à l'abandon. In: Pigeot, N. (Ed.), Derniers Magdaléniens d'Etiolles : perspectives culturelles et paléohistoriques, XXXVII ${ }^{\mathrm{e}}$ supplément à Gallia Préhistoire, Paris, pp. 107-160.

Christensen, M., Chollet, A., 2005. L'industrie sur bois de cervidé et os des niveaux magdaléniens et aziliens du Bois-Ragot: étude préliminaire. In: Chollet, A. Dujardin, V. (Eds.), La grotte du Bois-Ragot à Gouex (Vienne). Magdalénien et Azilien. Essais sur les hommes et leur environnement. Société Préhistorique Française, Paris, pp. 223-257.

Conkey, M., 1988. Les sites d'agrégation et la représentation de l'art mobilier ou y at-il des sites d'agrégation magdaléniens? In: Rigaud, J.-Ph., Laville, H., Vandermeersch, B. (Eds.), Le peuplement magdalénien : paléogéographie physique et humaine, Actes du colloque de Chancelade, 1988, Paris CTHS (Documents préhistoriques 2), pp. 19-25.

Coupaye, L., Douny, L., 2013. Dans la Trajectoire des Choses. Techniques \& Culture 52-53 [online]. http://tc.revues.org/4956.

Dari, A., 2003. Comportements de subsistance pendant la transition Paléolithique moyen-Paléolithique supérieur en Cantabrie à partir de l'étude archéozoologique des restes osseux des grands mammifères de la Grotte d'El Castillo (Puente Viesgo, Espagne). PhD Thesis. Muséum National d'Histoire Naturelle, Paris.

Féblot-Augustins, J., Perlès, C., 1992. Perspectives ethno-archéologiques sur les échanges à longue distance. In: l'Ethnoarchéologie : justification, problèmes, limites, XIIème rencontres d'Archéologie et d'Histoire d'Antibes. APDCA, Juanles-Pins, pp. 195-209.

Goutas N. Apport des fouilles récentes à la connaissance de l'exploitation des matières osseuses dans l'Aurignacien ancien de la Salle de Saint-Martin de la grotte d'Isturitz. Actes de la Table ronde d'Hasparren, 14 et 15 novembre 2003. In: Normand, Ch. (Ed.), Les recherches archéologiques dans les grottes d'Isturitz et Oxocelhaya de 1912 à nos jours: synthèse des résultats, Antiquités Nationales, numéro spécial (in press).

Goutas, N., 2013a. Nouvelles données sur l'industrie osseuse du Gravettien des grottes d'Arcy-sur-Cure (Yonne, France): vers l'identification de nouveaux marqueurs techniques et culturels du Gravettien moyen à burins du Raysse. In: Bodu, P., et al. (Eds.), Actes de la table ronde internationale: Le Paléolithique supérieur ancien de l'Europe du Nord-Ouest. Séance de la Société Préhistorique Française (15-18 avril 2009, musée de Sens, Yonne). Bulletin de la Société Préhistorique Française, hors-série, pp. 89-115.

Goutas, N., 2013b. De Brassempouy à Kostienki: l'exploitation technique des ressources animales dans l'Europe gravettienne. In: Otte, M. (Ed.), Les Gravettiens, édition Errance, Paris, pp. 105-160.

Goutas, N., 2013c. New data on the osseous Industry from Eastern Gravettian (Russia): technological analyses and sociological perspectives. In: Lang, F. (Ed.), 8th Meeting of the Worked Bone Research Group, Salzburg, August 29, September 3 2011, Archaeoplus, pp. 133-154.

Goutas, N., 2009. Réflexions sur une innovation technique gravettienne importante : le double rainurage. Bulletin de la Société préhistorique française 106 (3), 437-456.

Goutas, N., 2008. Les pointes d'Isturitz sont-elles toutes des armes de chasse ? CNRS éd. Gallia Préhistoire 50, 45-101.

Goutas, N., 2005. Apport des fouilles récentes à la connaissance de l'exploitation des matières osseuses dans l'Aurignacien ancien de la Salle de Saint-Martin de la grotte d'Isturitz: étude du matériel mis au jour en 2005 et synthèse des données depuis 2000. In: Normand, C. (Ed.), Isturitz (Salle de Saint-Martin). Rapport de fouilles programmées 2003-2005 et projet de recherche 2006-2008, non publié, déposé au S.R.A. Aquitaine.

Goutas, N., 2004. Caractérisation et évolution du Gravettien en France par l'approche techno-économique des industries en matières dures animales (étude de six gisements du Sud-ouest). Ph.D. Thesis. Paris 1 Panthéon-Sorbonne University, Paris.

Goutas, N., 2003a. Etude de l'industrie osseuse de l'Aurignacien d'Isturitz : campagne de fouilles 2003. In: Normand, C. (Ed.), Isturitz (Salle de Saint-Martin). Rapport de fouilles programmées 2003 et projet de recherches 2004, non publié, déposé au SRA Aquitaine.

Goutas, N., 2003b. Identification de deux procédés de débitage inédits du bois de Cervidés dans les niveaux gravettiens de Laugerie-Haute Est et Ouest. Paléo, 15, Les Eyzies de Tayac, pp. 255-262.

Goutas, N., Lacarrière, J., 2013. L'exploitation des cervidés dans le Gravettien d'Isturitz. Une approche archéozoologique et technologique des ressources animales : de leur acquisition à leur utilisation. In: de las Heras, C., Lasheras, J.A., Arrizabalaga, Á., de la Rasilla, M. (Eds.), Colloque International : Pensando el Gravetiense: nuevos datos para la región cantábrica en su contexto peninsular y pirenaico, Musée d'Altamira, Santillana del Mar, Cantabrie, Espagne (du 20 au 22 octobre 2011), pp. 565-592.

Groenen, M., 1994. Pour une histoire de la préhistoire. In: Le, Paléolithique (Ed.), Jérôme Million, collection. “L'Homme des Origines, Grenoble, pp. 287-302.

Haudricourt, 1964. La technologie, science humaine. La pensée 115, 28-35.

Haudricourt, 1965. L'origine des techniques. Courrier rationaliste 12, 32-36.

Haudricourt, 1968. La technologie culturelle, essai de méthodologie (en collaboration avec I. de Gagarine). In: Poirier, J. (Ed.), Ethnologie générale. Gallimard (la Pléiade), Paris, pp. 731-822.

Henri-Martin, L., 1930. La station aurignacienne de La Quina. Bulletin Mémoires de la Société Archéologique et Historique de la Charente 50, 5-84.

Inizan, M.-L., Reduron-Ballinger, M., Roche, H., Tixier, J., 1999. Terminology and Technology of Knapped Stone, Followed by a Multilingual Vocabulary, Translated by J. Féblot-Augustins. C.R.E.P. (Préhistoire de la Pierre Taillée 5), Nanterre, ISBN 2-903516-05-7.

Klaric, L., Guillermin, P., Aubry, T., 2009. Des armatures variées et des modes de productions variables : réflexions à partir de quelques exemples issus du Gravettien d'Europe occidentale (France, Portugal, Allemagne). Gallia Préhistoire, pp. 113-154.

Knecht, H., 1991. Technological Innovation and Design during the Early Upper Paleolithic: a Study of Organic Projectile. PhD Thesis. New York University, New York.

Knecht, H., 1997. Projectile points of bone, antler, and stone. Experimental explorations of manufacture and use. In: Knecht, H. (Ed.), Projectile Technology. Plenum Press, New York, pp. 191-212.

Lacarrière, J., Goutas, N., Lacarrière, J., Normand, Ch, Simonet, A., 2011. Vers une redéfinition des occupations gravettiennes de la grotte d'Isturitz (PyrénéesAtlantiques, France) : révision critique des collections « anciennes » par l'approche intégrée des données lithiques, fauniques et de l'industrie osseuse. In: Goutas, N., Klaric, L., Pesesse, D., Guillermin, P. (Eds.), À la recherche des identités gravettiennes. Actualités, questionnements et perspectives, Actes de la table ronde internationale du 6-8 octobre 2008, Aix-en-Provence, Mémoire LIII de la Société préhistorique française, pp. 67-83.

Lemonnier, P., 1993. Technological Choices. Transformation in Material Cultures since the Neolithic. Routledge, London.

Leroi-Gourhan, A., 1945-1973. Evolution et techniques. II, Milieu et techniques. Albin Michel, coll, Paris. Sciences d'aujourd'hui (third edition, corrected: 1973).

Leroi-Gourhan, A., 1943. Evolution et techniques. I, L'Homme et la matière. Sciences d'aujourd'hui, first ed. Albin Michel, coll, Paris.

Leroi-Gourhan, A., 1964. Le Geste et la Parole 1. Technique et langage. Albin Michel, coll, Paris. Sciences d'aujourd'hui. 
Liolios, D., 1999. Variabilité et caractéristiques du travail des matières osseuses au début de l'Aurignacien: Approche technologique et économique. PhD. Thesis. Paris X University, Paris.

Liolios, D., 2006. Reflections on the role of bone tools in the definition of the Early Aurignacian. In: Bar-Yosef, O., Zilhão, J. (Eds.), Towards a definition of the Aurignacian: proceedings of the symposium held in Lisbon, Portugal, June 25-30, 2002, Trabalhos de arqueologia, vol. 45, pp. 37-52.

Liouville, M., 2007. Variabilité du cerf Elaphe (Cervus Elaphus Linné 1758) au cours du Pléistocène moyen et supérieur en Europe occidentale : approches morphométrique, paléoécologique et cynégétique. PhD Thesis. Muséum National d'Histoire Naturelle, Paris.

Malgarini, R., 2014. Les gisements magdaléniens du Jura et des Alpes du nord et leurs industries osseuses. PhD Thesis. Unversity of Franche-Comté.

Mauss, M., 1936. Les techniques du corps. Journal de Psychologie 32, 271-293.

Mauss, M., 1947. Manuel d'ethnographie [Cours professé entre 1926-1939]. Payot, Paris, p. 89, 1971, 1947 [archive].

Moussette, M., 1984. Sens et contre-sens : l'étude de la culture matérielle au Québec. Canadian Folklore canadien 4, 11-15.

Mellars, P., 1989. Major issues in the emergence of modern humans. Current Anthropology 30 (3), 349-385.

Mellars, P., 2004. Neanderthals and the modern human colonization of Europe. Nature 432, 461-465.

Normand, Ch., Turq, A., 2007. Bilan des recherches 1995-1998 dans la Grotte d'Isturitz (communes d'Isturitz et de Saint-Martin-d'Arberoue, PyrénéesAtlantiques). In: Chauchat, Cl. (Ed.), Préhistoire du Bassin de l'Adour: bilans e perspectives, Actes du colloque de Saint-Étienne-de- Baïgorry, 19 janvier 2002, Izpegi, pp. 69-101.

Normand, Ch., Goutas, N., Lacarrière, J., Simonet, A., 2013. El Gravetiense de la cueva de Isturitz : nuevas investigaciones, nuevos datos. In: de las Heras, C. Lasheras, J.-A., Arrizabalaga, Á., de la Rasilla, M. (Eds.), Colloque International: Pensando el Gravetiense: nuevos datos para la región cantábrica en su contexto peninsular y pirenaico, Musée d'Altamira, Santillana del Mar, Cantabrie, Espagne (du 20 au 22 octobre 2011). Associacíon de amigos de museo de Altamira, pp. 161-183.

Nuzhnyi, D., 1998. The preliminary results of experiments with Aurignacian split based points production, hafting and usage. Préhistoire Européenne 13, $117-132$

Passemard, E., 1944. La caverne d'Isturitz en Pays basque. Préhistoire 9.

Pelegrin, J., 1990. Prehistoric lithic technology: some aspects of research. Archeological Review from Cambridge 9 (1), 116-125.

Pelegrin, J., 1991. Les savoir-faire : une très longue histoire. Terrain 16, 106-113.

Pelegrin, J., 1995. Technologie lithique: le Châtelperronien de Roc-de-Combe (Lot) et de La Côte (Dordogne). In: Cahiers du Quaternaire, vol. 20. CNRS Editions, Paris.

Pelegrin, J., 2004. Le milieu intérieur d'André Leroi-Gourhan et l'analyse de la taille de pierre au Paléolithique (dir.). In: Audouze, F., Schlanger, N. (Eds.), Autour de l'homme: contexte et actualité d'André Leroi-Gourhan. Editions APDCA, Antibes, pp. 149-162.

Perlès, C., 2012. Quand diffusion ne veut pas dire interaction, Congrés Internaciona Xarxes al Neolític - Neolithic Networks Rubricatum. Revista del Museu de Gavà $5,1135-3791$.

Pétillon, J.-M., 2006. Des magdaleniens en armes. Technologie des armatures de projectile en bois de cervide du Magdalenien supérieur de la Grotte d'Isturitz (Pyrénnées-Atlantiques). In: Artefacts, vol. 10. CEDARC, Treignes.

Pétillon, J.-M., Langlais, M., Kuntz, D., Normand, Ch., Barshay-Szmidt, C., Costamagno, S., Delmas, M., Laroulandie, V., Marsan, G., 2015. The human occupation of the northwestern Pyrenees in the Late Glacial: new data from the Arudy basin, lower Ossau valley. Quaternary International 364, 126-143.

Peyrony, D., 1933. Les industries "aurignaciennes" dans le bassin de la Vézère. Bulletin de la Societé Préhistorique Française 30, 543-559.

Peyrony, D., 1934. La Ferrassie: Moustérien, Périgordien, Aurignacien. Préhistoire III.

Peyrony, D., 1935. Le gisement Castanet, Vallon de Castelmerle, Commune de Sergeac (Dordogne). Aurignacien I et II. Bulletin de la Société Préhistorique Française 42, 418-443.

Pigeot, N., 1987. Magdaléniens d'Etiolles. In: Économie de débitage et organisation sociale, supplément à Gallia Préhistoire, vol. 25. CNRS, éditions, Paris.

Ploux, S., 1989. Approche archéologique de la variabilité des comportements techniques individuels. Les tailleurs de l'unité 27-M89 de Pincevent. PhD Thesis. Paris X University, Nanterre.

Rémy, D. 2013. Caractérisation techno-économique d'industries en bois de cervidés du Badegoulien et du Magdalénien : le cas du Rond-du-Barry (Haute-Loire) et de Rochereil (Dordogne). Mémoire de doctorat de Montpellier III.

de Saint-Périer, R.S., de Saint-Périer, 1952. La grotte d'Isturitz III: les Solutréens, les Aurignaciens et les Moustériens. In: Archives de l'Institut de Paléontologie Humaine. Masson, Paris.

Sigaut, F., 1987. Haudricourt et la Technologie (Préface). In: André-Gorges Haudricourt, la technologie science humaine. Recherches d'histoire et d'ethnologie des techniques, édition de la Maison des Sciences de l'homme. FMSH, pp. 9-36.

Simonet, A., 2011. La pointe des Vachons : nouvelles approches d'un fossile directeur controversé du Gravettien à partir des exemplaires du niveau IV de la grotte d'Isturitz (Pyrénées-Atlantiques, France) et des niveaux 4 des abris 1 et 2 des Vachons (Charente, France). Paleo 22, 271-298 [online on Revues.org].

Soulier, M.-C., Goutas, N., Normand, C., Legrand, A., White, R., 2014. Regards croisés de l'archéozoologue et du technologue sur l'exploitation des ressources animales à l'Aurignacien archaïque: l'exemple d'Isturitz (Pyrénées-Atlantiques, France) (dir.). In: Thiébault, C., Costamagno, S., Claud, E. (Eds.), Exploitation des ressources organiques à la fin du Paléolithique moyen et au début du Paléolithique supérieur: interactions entre environnement et comportements techniques, XXVIle Congrès Préhistorique de France. Mémoires de la Société Préhistorique Française, pp. 315-332.

Taborin, Y., 2004. Langage sans parole: la parure aux temps préhistoriques. la Maison des roches, Paris.

Tartar, E., 2009. De l'os à l'outil - caractérisation technique, économique et sociale de l'utilisation de l'os à l'aurignacien ancien. Étude de trois sites : l'Abri Castanet (secteurs nord et sud), Brassempouy (Grotte des Hyènes et Abri Dubalen) et Gatzarria. PhD Thesis. Paris 1 Panthéon-Sorbonne University, Paris.

Tartar, E., White, R., 2013. The manufacture of Aurignacian split-based points: an experimental challenge. Journal of Archaeological Science 40, 2723-2745.

Tejero, J.-M., 2010. La explotación de las materias duras animales en el Paleolítico superior inicial. Una aproximación tecno-económica a las producciones óseas auriñacienses en la Península Ibérica. PhD Thesis. UNED University, Madrid.

Tejero, J.-M., 2013. La explotación de las materias óseas en el Auriñaciense. Caracterización tecnoeconómica de las producciones del Paleolítico superior inicial en la Península Ibérica. In: British Archaeological Reports. International Series, vol. 2469. Archaeopress, Oxford.

Tejero, J.-M., 2014. Towards complexity in osseous raw material exploitation by the first Anatomical modern humans in Europe: Aurignacian Deer Antler Work. Journal of Anthropological Archaeology 36, 72-92.

Tejero, J.-M. Spanish Aurignacian projectile points. An example of the first European Palaeolithic hunting weapons in osseous material. In: Langley, M. (Ed.), Osseous Projectile Weaponry: towards an Understanding of Pleistocene Cultural Variability. Cambridge University Press, Cambridge (in press).

Tejero, J.-M., Christensen, M., Bodu, P., 2012. Red deer antler technology and early modern humans in Southeast Europe: an experimental study. Journal of Archaeological Science 39, 332-346.

Tejero, J.-M., Avezuela, B., White, R., Ramlett, S., Quam, R., Tattersall, I., Bernaldo De Quirós, F. 2010. Un pedazo de la Prehistoria cántabra en Nueva York. Las Colecciones de la Cueva de El Castillo (Puente Viesgo, Cantabria) en el American Museum of Natural History (Nueva York, EEUU). Munibe 61, 5-16.

Tejero, J.-M., Grimaldi, S., 2015. Assessing bone and antler exploitation at Riparo Mochi (Balzi Rossi, Italy): Implications for the characterization of the Aurignacian in South-western Europe. Journal of Archaeological Science 61, 59-77.

Teyssandier, N., 2007. En route vers l'ouest. Les débuts de l'aurignacien en Europe. In: British Archaeological Reports. International Series, 1638. Hadrian Books, Oxford.

Teyssandier, N., 2008. Revolution or evolution: the emergence of the Upper Paleolithic in Europe. World Archaeology 40, 493-519.

Teyssandier, N., Bon, F., Bordes, J.-G., 2010. Within projectile range: some thoughts on the Appearance of the Aurignacian in Europe. Journal of Anthropological Research 66, 209-229.

Tixier, J.-P., 1980. Raccords et remontages en Préhistoire. In: Tixier, J. (Ed.), Préhistoire et technologie lithique. Centre National de la Recherche Scientifique. CRA, Valbonne, pp. 50-55.

Valentin, B., 1995. Les groupes humains et leurs traditions au Tardiglaciaire dans le Bassin Parisien. Apports de la technologie lithique comparée. PhD Thesis. Paris 1 University.

Valentin, B., 2006. De l'Oise à la Vienne, en passant par le Jourdain. Jalons pour une paléohistoire des derniers chasseurs, mémoire de thèse d'habilitation à diriger des recherches. Paris 1 Panthéon-Sorbonne, Paris.

Valentin, B., 2008. Typologie vs typologie (Sic !). Comment la technologie contribue à raffiner la typologie des armatures lithiques. In: Aubry, T. Almeida, F. Araújo, A.-C., Tiffagom, M. (Eds.), Space and Time: Which Diachronies, Which Synchronies, Which Scales? Typology vs. Technology. Proceedings of the XV World Congress of the International Union for Prehistoric and Protohistoric Sciences, 21, Sections C64 and C65, pp. 189-196.

Vanhaeren, M., 2002. Les fonctions de la parure au Paléolithique supérieur: de l'individu à l'unité culturelle. PhD Thesis. Bordeaux I University, Bordeaux, p. 355.

White, R., 2007. Systems of personal ornamentation in the early Upper Palaeolithic: methodological challenges and new observations. In: Mellars, P., et al. (Eds.) Rethinking the Human Revolution: New Behavioural and Biological Perspectives on the Origin and Dispersal of Modern Humans. McDonald Insitute for Archaeological Research, Cambrigde, pp. 287-302. 